\title{
EVALUATION OF THE FERTILITY STATUS OF SELECTED SOILS IN MBAISE, IMO STATE SOUTHEASTERN NIGERIA USING NUTRIENT INDEX METHOD
}

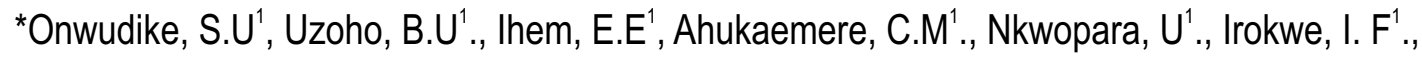 \\ and Echeanyanwu, G.I'. \\ ${ }^{1}$ Department of Soil Science and Technology, Federal University of Technology of Owerri, Imo \\ State Nigeria \\ *onwudikestanley@yahoo.com
}

\begin{abstract}
This study was carried out to evaluate the fertility status of soils in Ahiazu Mbaise, Imo State under three land use types using nutrient index method and fertility rating. Soil samples were collected from five sampling points each from three land use types at the depth of $020 \mathrm{~cm}$. Samples were prepared and analysed for physical properties such as particle size distribution, bulk density, moisture content, total porosity and also soil chemical properties such as soil pH, organic carbon, total nitrogen, available phosphorus, exchangeable bases and base saturation . Data generated from laboratory analysis were subjected to statistical analysis. Results obtained showed that irrespective of the land use, soils of the study area were moderately acidic with high sand fraction (> $70 \%)$ resulting to poor physical condition such as poor moisture retention and total porosity. The chemical properties showed low organic matter content (15.8 $29.1 \mathrm{~g} / \mathrm{kg}$ ), low total nitrogen $(0.71 .5$ $\mathrm{g} / \mathrm{kg}$ ) and available phosphorus (3.1 $5.6 \mathrm{mg} / \mathrm{kg}$ ). The exchangeable bases were low and below the critical limits with predominant exchangeable $H$ and Al. Soil nutrient depletion followed this order: fallow land > palm plantation > cassava cultivated land. Results also showed little variability in soil physicochemical properties in the three land use types. Results of the nutrient index and fertility rating also showed that soils of the study locations were extremely poor in fertility with a fertility rating of 1 and nutrient index of 1 in the three land uses signifying poor fertility status when compared to standard ratings. Therefore, to improve the quality and fertility level of soils in these locations, there is urgent need to adopt strategic management measures and agronomic principles that will improve the fertility levels.
\end{abstract}

Key words: Soil fertility, Nutrient index, Organic matter, land use, Ultisol

\section{INTRODUCTION}

Food security has been a major challenge facing many developing countries at present. In Southeastern Nigeria, people spend over $70 \%$ of their monthly income on food due to high cost of food items (Senjobi, 2007). John et al. (2013) have reported that one of the greatest problems facing most African countries is the inability to grow enough food for her increasing population. This problem has resulted to malnutrition and poverty among the rural dwellers (Senjobi, 2007). Investigations have shown that soil infertility due to land degradation has been a major constraint to food production (Agbede and Adekiya, 2012; Eswaran et al., 2001). 
These problems have resulted into adoption of many strategies aimed at improving soil productivity and crop yield. Among these strategies, was the use of agricultural and domestic solid wastes as soil amendments (Tekwa and Bethel, 2008; Oladipo et al., 2010). Land use types as a result of cropping system and anthropogenic activities have shown to alter soil properties over time together with high precipitation and tillage practices. Understanding the distributions of soil properties at the field scale is important for refining agricultural management practices and assessing the effects of agriculture on environmental quality (Cambardella et al., 1994).

The fertility status of soils can be evaluated using nutrient index methods and fertility indicators. Ravikumar and Somashekar (2013) evaluated the nutrient index of soil using organic carbon, available P and available K concentrations as a measure of soil fertility in Varahi River basin, India. Variability in the physico-chemical properties of soils in some land use types in Ahiazu Mbaise has been evaluated in recent times (Onwudike et al., 2015). However, the fertility status of soils in Mbaise has not been thoroughly studied to ascertain the present fertility conditions of the soil for proper management and for efficient crop productivity using nutrient index method and fertility ratings. In line with this, it therefore becomes pertinent to study the present fertility status of some of these soils which has been subjected to different land uses. This study therefore aimed at evaluating the fertility status of selected soils in three land use types in Mbaise, using fertility ratings and nutrient index and to determine the variability existing among soil physicochemical properties.

\section{Materials and Methods.}

The Study Area: This study was conducted at three villages in Mpam in Ahiazu Mbaise Local Government Area of Imo State. The coordinates of the area were Okponkume Mpam (Longitude $7^{\circ}$ $43^{\prime} \mathrm{E}$ and latitude $7^{\circ} 62^{\prime} \mathrm{N}$ ), Nnemere Mpam (Longitude $7^{\circ} 53^{\prime} \mathrm{E}$ and latitude $7^{\circ} 34^{\prime} \mathrm{N}$ ) and Umuohuo Mpam (Longitude $7^{\circ} 52^{\prime} \mathrm{E}$ and latitude $7^{\circ} 41^{\prime} \mathrm{N}$ ). The area has an altitude of $140 \mathrm{~m}$ above sea level. The area has annual rainfall range from $2500 \mathrm{~mm}$ to $3000 \mathrm{~mm}$ and an annual temperature range of 26- $32^{\circ} \mathrm{C}$. The area falls within the tropical zone with climate characterized by rainy season (February/March November) and dry season (November February/March). The soils of the area are predominantly Ultisol derived from Coastal Plain sand (Benin formation) and are characterized by low $\mathrm{pH}$, low organic matter and exchangeable bases. Tropical crops such as palm trees, raffia palms, and other cash crops dominated the area (Onwudike, 2010). Soil fertility restoration in the area is through application of mineral fertilizers and organic manures. Farming and trading are the major socio economic activities of people in the area (Onwudike et al., 2015, Onweremadu, 2007).

Soil Sampling and Experimental Design: A reconnaissance visit was made to the study locations to locate the sampling sites and to obtain information from the owners about the sites. Fallow land, cassava cultivated land and palm plantation farm were studied. Samples were collected from three villages out of five communities that made up Mpam in Ahiazu Mbaise, Imo State whose soils are of the same parent material and exposed to the same climatic conditions. The communities were Okponkume Mpam, Nnemere Mpam and Umuohuo Mpam. In each of the villages, five soil samples were collected each from five fallow lands that are under fallow for three years, dominated by shrubs 
and grasses; five cassava cultivated lands with similar management practices and from five palm plantation farms that are over ten years. Samples were collected at the root zone of $0-20 \mathrm{~cm}$ using soil auger and core samplers for bulk density. The five sample points act as replications while the three land use types act as treatments. The samples were collected in a randomized complete block design. Apart from samples collected using core samplers for bulk density determination, other samples were air-dried, sieved using $2 \mathrm{~mm}$ sieve and then subjected to laboratory analysis using standard methods.

Laboratory Analysis: Particle Size Analysis (PSA): This was determined using hydrometer method with Sodium hexametaphosphate (Calgon) as dispersal agent according to Gee and Or (2002) and the textural class determined using textural triangle.Bulk Density (BD) was determined using the core method according to Grossman and Reinsch (2002) using the formula which is calculated mathematically as follows:

Bulk density $(\mathrm{BD})=\mathrm{V}_{\mathrm{t} 1} / \mathrm{V}_{\mathrm{t} 2}$ equation 1.

where $\mathrm{V}_{\mathrm{t} 1}=$ Mass of oven-dried soil and $\mathrm{V}_{\mathrm{t} 2}=$ Volume of core sampler.

Total Porosity $\left(\mathrm{P}_{\mathrm{t}}\right)$. This was calculated from bulk density as

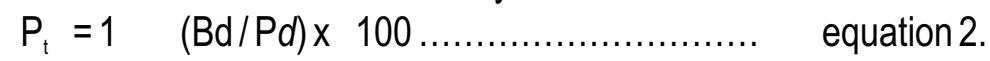

where $P d=$ particle density $(2.65)$

Moisture content was determined by the gravimetric method calculated mathematically as follows:

$$
\% \text { M.C }=\left\{\left(\mathrm{W}_{2} \mathrm{~W}_{3}\right) /\left(\mathrm{W}_{3} \mathrm{~W}_{1}\right)\right\} \times 100 \ldots \ldots \ldots \ldots \ldots . . . \text { equation } 3 .
$$

where; $W_{1}=$ weight of the can, $W_{2}=$ weight of wet sample + can, $W_{3}=$ weight of oven-dried sample + can.

Soil $\mathrm{pH}$ was determined in distilled water (at the ratio of 1:2:5) and in $\mathrm{KCl}$ solution according to Mclean, (1982). Total Nitrogen was determined using the modified micro-kjedhal digestion method of Bremner and Yeomans (1988). Organic Carbon was determined using the Walkley and Black wet oxidation technique (Nelson and Sommers, 1982). Available P was extraction with Bray II solution according to Olsen and Summers (1982). Exchangeable Bases (Ca, Mg, Na and K) were extracted using Ammonium acetate solution buffered at $\mathrm{pH} 7$ (Thomas, 1982). The exchangeable $\mathrm{Ca}$ and $\mathrm{Mg}$ were determined by EDTA complex metric titrations while the exchangeable $\mathrm{Na}$ and $\mathrm{K}$ was determined using the flame photometer. Exchangeable Acidity (EA) was measured titrimetrically using $1 \mathrm{~N} \mathrm{KCl}$ against 0.05N Sodium hydroxide (McLean, 1982) Effective Cation Exchange Capacity (ECEC) was determined by the summation of all exchangeable bases and exchangeable acidity. Base saturation was obtained mathematically as follows:

$$
\% \text { B.S }=[\text { TEB] } /[\text { ECECX 100] }
$$

where; $\mathrm{TEB}=$ Total Exchangeable Bases ( $\mathrm{Ca}, \mathrm{Mg}$, Na and $\mathrm{K}$ ).

Nutrient Index Determination: The nutrient index was evaluated using the nutrient index specific rating chart according to Ravikumar and Somashekar (2013). The nutrient index with respect to soil $\mathrm{pH}$, organic carbon, available $\mathrm{P}$, and exchangeable $\mathrm{k}$ were used to evaluate the fertility status of the soil in the three land uses. The rating chart is shown below; 
Table 1: Rating chart for nutrient index used in the study

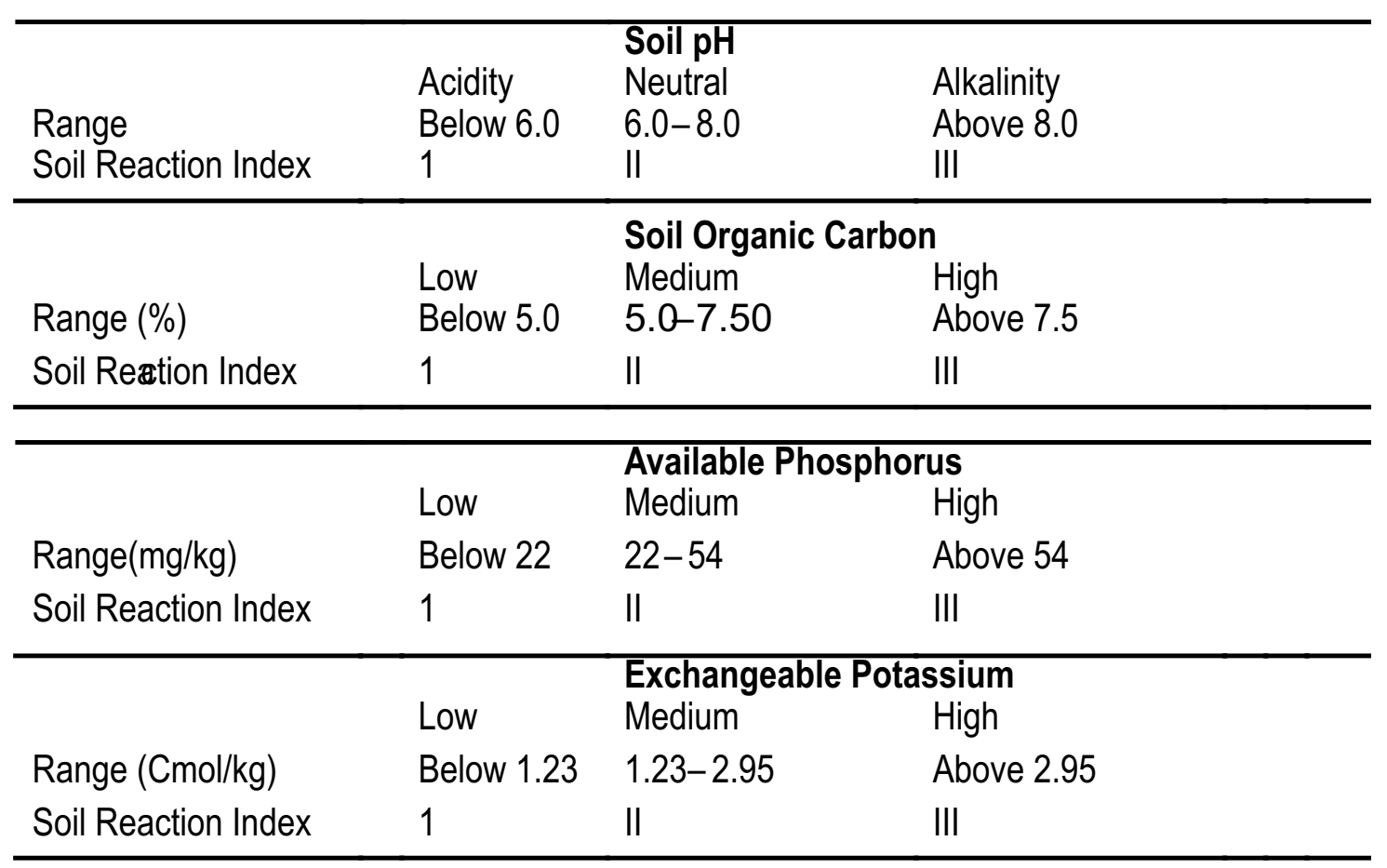

The nutrient index in soils were calculated using the method adopted by Ravikumar and Somashekar (2013) as

Nutrient Index $=\{(1 \times A)+(2 X B)+(3 X C)\} /$ TNS

where $A=$ Number of samples in low category; $B=$ Number of sample in medium category;

$\mathrm{C}=$ Number of sample in High category, TNS $=$ Total number of samples

The nutrient Index with range and remark according to Ravikumar and Somashekar (2013) used in the study is presented below:

\begin{tabular}{lll}
\hline Nutrient Index & Range & Remark (for OC, Available P and Exchangeable K \\
\hline I & Below 1.67 & Low \\
II & 1.67-2.33 & Medium \\
III & Above 2.33 & High \\
\hline
\end{tabular}


Data collected were subjected to Analysis of Variance (ANOVA) using Genstat (Third Edition) software. Significant means were separated using Least Significant Difference (LSD) at 0.05 probability level. Variability among soil physical and chemical properties were determined using coefficient of variation and ranked according to Wilding et al., (1994) as \%CV from $015=$ low variation, $1535=$ medium variation and above $35=$ high variation.

\section{Results and Discussions}

\section{The Physical Properties of Soils in the Study Area}

Results of the physical properties of soil in the study locations are presented in Table 2. Results showed that texturally, the soils ranged from sandy loam to sandy with sand fraction dominating the particle size distribution. The sand, silt and clay fractions in the fallow land were $785.4 \mathrm{~g} / \mathrm{kg}, 89 \mathrm{~g} / \mathrm{kg}$ and $125.6 \mathrm{~g} / \mathrm{kg}$ respectively. In cassava farm, the sand, silt and clay fractions were $822.8 \mathrm{~g} / \mathrm{kg}$, $77.4 \mathrm{~g} / \mathrm{kg}$ and $117.6 \mathrm{~g} / \mathrm{kg}$ respectively while in palm plantation, the sand, silt and clay were $789.6 \mathrm{~g} / \mathrm{kg}$, 74 and $139.4 \mathrm{~g} / \mathrm{kg}$ respectively. The high sand fraction in the study locations could be attributed to the parent material dominant in the area which is coastal plain sand since the texture of the soil is highly influenced by the parent material over time (Oguike and Mbagwu, 2009). This result agreed with Onweremadu (2007) who observed similar textural characteristics on coastal plain soils in Owerri, Southeastern Nigeria. Also, the humid rainfall characteristics that promote illuviation or leaching of silt and clay particles below the epipedon could contribute to the texture of soils in the area.

The bulk density of the soils ranged from 1.018 to $1.104 \mathrm{~g} / \mathrm{cm}^{3}$ with palm plantation recording the lowest bulk density of $1.018 / \mathrm{cm}^{3}$ and the highest bulk density $\left(1.104 \mathrm{~g} / \mathrm{cm}^{3}\right)$ was recorded in cassava farm land. The high bulk density recorded in cassava land could be attributed to tillage activities. Fallow land and palm plantation do not experience continuous cultivation unlike cassava farm and therefore, tillage activities could reduce organic matter accumulation which reduces soil bulk density. However, the values of bulk densities were below the critical limit of $1.3 \mathrm{~g} / \mathrm{cm}^{3}$ recommended for tuber and cereal crops (Kayombo and Lal, 1984).

Soil total porosity ranged from 58.36 to $61.54 \%$ with the highest $61.54 \%$ in palm plantation and the lowest of $58.36 \%$ in cassava cultivated land. Increase in soil bulk density resulted to a decrease in soil total porosity which could be attributed to compaction of soil macro and micro pore spaces (Onweremadu, 2007). The highest moisture content was recorded in fallow land with $476.8 \mathrm{~g} / \mathrm{kg}$ of moisture retention; this was followed by palm plantation (421.0) and least by cassava cultivated land $(375.2 \mathrm{~g} / \mathrm{kg})$. The low moisture retention could be attributed to the high sand fraction and low porosity which hinders moisture retention. Soils with this property lack absorption capacity for basic plant nutrient and water retention (Oguike and Mbagwu, 2009). 
Onwudike, Uzoho, Ihem, Ahukaemere, Nkwopara, Irokwe \& Echeanyanwu

Table 2: Physical properties of the study locations

\begin{tabular}{|c|c|c|c|c|c|c|c|c|}
\hline Land Use & $\begin{array}{l}\text { Depth } \\
\mathrm{Cm}\end{array}$ & $\begin{array}{l}\text { Sand } \\
\mathrm{g} / \mathrm{kg}\end{array}$ & $\begin{array}{l}\text { Silt } \\
\text { g/kg }\end{array}$ & $\begin{array}{l}\text { Clay } \\
\text { g/kg }\end{array}$ & TC & $\begin{array}{l}\mathrm{BD} \\
\mathrm{g} / \mathrm{cm} 3\end{array}$ & $\begin{array}{l}\text { TP } \\
\%\end{array}$ & $\begin{array}{l}\mathrm{MC} \\
\mathrm{g} / \mathrm{kg}\end{array}$ \\
\hline Fallow Land & $0-30$ & 764 & 80 & 156 & $\overline{S L}$ & 1.02 & 61.5 & 437 \\
\hline Fallow Land & $0-30$ & 744 & 100 & 156 & SL & 0.94 & 64.5 & 395 \\
\hline Fallow Land & $0-30$ & 864 & 60 & 76 & LS & 1.23 & 53.6 & 411 \\
\hline Fallow Land & $0-30$ & 755 & 105 & 140 & SL & 0.87 & 67.2 & 543 \\
\hline Fallow Land & $0-30$ & 800 & 100 & 100 & SL & 1.11 & 58.1 & 598 \\
\hline Mean & & 785.4 & 89 & 125.6 & & 1.034 & 60.98 & 476.8 \\
\hline Cassava Farm & $0-30$ & 844 & 40 & 116 & LS & 1.13 & 57.4 & 453 \\
\hline Cassava Farm & $0-30$ & 824 & 60 & 116 & LS & 1.15 & 56.6 & 422 \\
\hline Cassava Farm & $0-30$ & 804 & 80 & 116 & LS & 1.11 & 58.1 & 314 \\
\hline Cassava Farm & $0-30$ & 827 & 92 & 140 & $S$ & 1.04 & 60.8 & 322 \\
\hline Cassava Farm & $0-30$ & 815 & 115 & 100 & $S$ & 1.09 & 58.9 & 365 \\
\hline Mean & & 822.8 & 77.4 & 117.6 & & 1.104 & 58.36 & 375.2 \\
\hline Palm Plantation & $0-30$ & 744 & 100 & 156 & $S L$ & 0.89 & 66.4 & 532 \\
\hline Palm Plantation & $0-30$ & 844 & 40 & 116 & $S L$ & 1.12 & 57.7 & 315 \\
\hline Palm Plantation & $0-30$ & 764 & 60 & 176 & SL & 0.98 & 63 & 476 \\
\hline Palm Plantation & $0-30$ & 842 & 100 & 73 & $S$ & 1.11 & 58.1 & 317 \\
\hline Palm Plantation & $0-30$ & 754 & 70 & 176 & SL & 0.99 & 62.6 & 465 \\
\hline Mean & & 789.6 & 74 & 139.4 & & 1.018 & 61.56 & 421.0 \\
\hline $\operatorname{LSD}(0.05)$ & & NS & NS & NS & & NS & NS & NS \\
\hline
\end{tabular}

SL = Sandy Loam, LS = Loamy sand, $\mathrm{S}=$ Sandy, TC = Textural Class, BD = Bulk density, TP = Total Porosity, MC = Moisture Content. NS = not significant at $5 \%$

\section{Soil Chemical Properties of the Study Locations}

The soil chemical properties of the study locations are presented in Table 3. Result showed that the soils were moderately acidic with $\mathrm{pH}$ of 5.92 in fallow land, 5.3 in cassava cultivated land and 5.86 in palm plantation. This conformed to the works of Onwudike et al. (2015) and Mbah (2006) who got similar results in the region. The highest soil $\mathrm{pH}$ in fallow land could be attributed to litter falls which after decomposition increases soil organic matter and exchangeable bases thereby reducing the accumulation of $\mathrm{H}$ and $\mathrm{Al}$ ions on soil exchange complex (Onwudike, 2010).

Soil organic carbon ranged from 9.1 to $16.8 \mathrm{~g} / \mathrm{kg}$. Onwudike et al. (2015) recorded the range of 5.4 $13.2 \mathrm{~g} / \mathrm{kg}$ in selected land use types around the region. The highest soil organic carbon was recorded in the fallow land $(16.8 \mathrm{~g} / \mathrm{kg})$ followed by palm plantation $(14.4 \mathrm{~g} / \mathrm{kg})$ and the least was 9.1 $\mathrm{g} / \mathrm{kg}$ in cassava cultivated land. The highest organic carbon in the fallow land could be due to litter fall and expected increase in soil biodiversity (Miller and Gardiner, 2001). Woldeamlak and Stroosnijder (2003) have observed thatconversion of forest vegetation to agricultural land results in 
a decline of the soil organic carbon content. This could be the reason for the low organic carbon recorded in cassava cultivated land.

The same trend above was observed in soil total nitrogen with the highest value of $1.5 \mathrm{~g} / \mathrm{kg}$ in forest land, $1.2 \mathrm{~g} / \mathrm{kg}$ in palm plantation and the least of $0.7 \mathrm{~g} / \mathrm{kg}$ in cassava cultivated land. Similarly, fallow land recorded the highest available phosphorus of $5.6 \mathrm{mg} / \mathrm{kg}$ and the least $(3.1 \mathrm{mg} / \mathrm{kg})$ was in cassava cultivated land. High total nitrogen and available phosphorus recorded in fallow land could be due to litter fall and higher soil organisms that help in organic matter decomposition since there is a positive correlation between organic matter and total nitrogen (Onwudike, 2010). High available phosphorus in the fallow land could be due to high soil pH values and soil organic carbon that reduce phosphorus fixation in the soil (Mbah, 2006).

The exchangeable cations were low in the three land types with the highest values recorded in fallow lands. Exchangeable $\mathrm{Ca}, \mathrm{Mg}, \mathrm{K}$ and $\mathrm{Na}$ in fallow land were $2.2,1.51,0.19$ and $0.33 \mathrm{cmol} / \mathrm{kg}$ respectively. In cassava cultivated land the values were $2.14,1.3,0.11$ and $0.15 \mathrm{cmol} / \mathrm{kg}$ respectively while in palm plantation the values were $2.1,1.26,0.19$ and $0.34 \mathrm{cmol} / \mathrm{kg}$ respectively. The low exchangeable bases using fertility indices in these locations could be due to high rainfall which accelerates runoff and leaching down the subsoil. Higher exchangeable bases in the fallow land could be due to the macro and micro climate that hinders the impact of rain drops on soil (Brady and Weil, 2002).

On the exchangeable $\mathrm{Al}$ and $\mathrm{H}$, fallow lands recorded the lowest values of exchangeable $\quad A \quad I$ and $\mathrm{H}$ with values 0.3 and $0.22 \mathrm{Cmol} / \mathrm{kg}$ respectively. This was followed by palm plantation with values 0.4 and $0.26 \mathrm{Cmol} / \mathrm{kg}$ respectively and the highest values were on cassava cultivated land with values 0.44 and $0.28 \mathrm{Cmol} / \mathrm{kg}$ respectively. Lower values of exchangeable $\mathrm{Al}$ and $\mathrm{H}$ in fallow land could be attributed to high soil $\mathrm{pH}$, high organic carbon and vegetation cover that reduces run off of plant nutrients thereby reducing accumulation of $\mathrm{Al}$ and $\mathrm{H}$ ions on exchange complex (Brady and Weil, 2002). The above trend was not observed on ECEC and percentage base saturation. Fallow land recorded the highest ECEC and base saturation of $4.75 \mathrm{Cmol} / \mathrm{kg}$ and $84.9 \%$ respectively. This was followed by palm plantation with values $4.59 \mathrm{Cmol} / \mathrm{kg}$ and $83.7 \%$ respectively and the lowest was on cassava cultivated land with values $4.42 \mathrm{Cmol} / \mathrm{kg}$ and $82.4 \%$ respectively. High ECEC and base saturation in fallow land could be attributed to increase in exchangeable bases and organic carbon obtained from mineralization of litter falls in fallow land. 
Onwudike, Uzoho, Ihem, Ahukaemere, Nkwopara, Irokwe \& Echeanyanwu

Table 3: The chemical properties of the studied soils

\begin{tabular}{|c|c|c|c|c|c|c|c|c|c|c|c|c|c|c|}
\hline & & & & & & Avail. & & & & Exch & & & & \\
\hline Land Use & $\begin{array}{l}\text { Depth } \\
\mathrm{Cm}\end{array}$ & $\begin{array}{l}\mathrm{PH} \\
\left(\mathrm{H}_{2} \mathrm{O}\right)\end{array}$ & $\begin{array}{l}\text { OC } \\
\mathrm{g} / \mathrm{kg}\end{array}$ & $\begin{array}{l}\text { OM } \\
\mathrm{g} / \mathrm{kg}\end{array}$ & $\begin{array}{l}\mathrm{TN} \\
\mathrm{g} / \mathrm{kg}\end{array}$ & $\begin{array}{l}\mathrm{P} \\
\mathrm{Mg} / \mathrm{kg}\end{array}$ & $\mathrm{Ca}$ & $\mathrm{Mg}$ & K & $\mathrm{Na}$ & $\begin{array}{l}\mathrm{Al} \\
\mathrm{cmol} / \mathrm{kg}-\end{array}$ & $\mathrm{H}$ & $\stackrel{\text { ECEC }}{\longrightarrow}$ & $\begin{array}{l}\text { BS } \\
\%\end{array}$ \\
\hline Fallow Land & $0-30$ & 5.94 & 15.9 & 27.4 & 1.3 & 4.86 & 2.2 & 1.6 & 0.21 & 0.09 & 0.3 & 0.2 & 4.6 & 89.1 \\
\hline Fallow Land & $0-30$ & 6.09 & 26.1 & 45.2 & 2.2 & 12.2 & 2.8 & 1.2 & 0.27 & 0.12 & 0.4 & 0.2 & 4.99 & 88 \\
\hline Fallow Land & $0-30$ & 5.67 & 11.2 & 19.3 & 0.9 & 2.3 & 2 & 1.6 & 0.14 & 0.23 & 0.4 & 0.3 & 4.67 & 85 \\
\hline Fallow Land & $0-30$ & 6.1 & 16.5 & 28.4 & 2 & 5 & 2.1 & 1.5 & 0.21 & 0.1 & 0.2 & 0.3 & 4.41 & 70.3 \\
\hline Fallow Land & $0-30$ & 5.82 & 14.5 & 25 & 1.3 & 3.5 & 1.8 & 1.65 & 0.13 & 1.12 & 0.3 & 0.1 & 5.1 & 92.1 \\
\hline $\begin{array}{l}\text { Mean } \\
\text { Cassava }\end{array}$ & & 5.92 & 16.8 & 29.1 & 1.5 & 5.6 & 2.2 & 1.51 & 0.19 & 0.33 & 0.3 & 0.22 & 4.75 & 84.9 \\
\hline Farm & $0-30$ & 5.36 & 10.9 & 18.8 & 0.9 & 6.36 & 2 & 1.2 & 0.15 & 0.17 & 0.5 & 0.3 & 4.32 & 81.5 \\
\hline $\begin{array}{l}\text { Cassava } \\
\text { Farm }\end{array}$ & $0-30$ & 5.21 & 6.9 & 12.1 & 0.6 & 2.61 & 3.4 & 1.6 & 0.07 & 0.16 & 0.7 & 0.2 & 6.13 & 85.3 \\
\hline $\begin{array}{l}\text { Cassava } \\
\text { Farm } \\
\text { Cassava }\end{array}$ & $0-30$ & 5.18 & 8.9 & 15.5 & 0.7 & 2.39 & 1.6 & 1 & 0.26 & 0.13 & 0.3 & 0.4 & 3.69 & 81 \\
\hline $\begin{array}{l}\text { Farm } \\
\text { Cassava }\end{array}$ & $0-30$ & 5.5 & 10.3 & 17.8 & 0.7 & 1.5 & 2.01 & 1.15 & 0.12 & 0.13 & 0.35 & 0.3 & 4.06 & 83.9 \\
\hline Farm & $0-30$ & 5.2 & 8.5 & 14.7 & 0.5 & 2.5 & 1.7 & 1.4 & 0.09 & 0.15 & 0.37 & 0.2 & 3.91 & 87 \\
\hline $\begin{array}{l}\text { Mean } \\
\text { Palm }\end{array}$ & & 5.3 & 9.1 & 15.8 & 0.7 & 3.1 & 2.14 & 1.3 & 0.14 & 0.15 & 0.44 & 0.28 & 4.42 & 83.7 \\
\hline $\begin{array}{l}\text { Plantation } \\
\text { Palm }\end{array}$ & $0-30$ & 5.87 & 18.5 & 32 & 1.6 & 4.91 & 1.6 & 1.2 & 0.27 & 0.19 & 0.4 & 0.2 & 3.86 & 84.5 \\
\hline $\begin{array}{l}\text { Plantation } \\
\text { Palm }\end{array}$ & $0-30$ & 6.39 & 15.5 & 26.9 & 1.3 & 5.62 & 2.0 & 1.2 & 0.14 & 0.17 & 0.4 & 0.3 & 4.21 & 83.4 \\
\hline $\begin{array}{l}\text { Plantation } \\
\text { Palm }\end{array}$ & $0-30$ & 5.75 & 10.3 & 17.9 & 0.5 & 3.12 & 3.2 & 1.6 & 0.22 & 0.13 & 0.3 & 0.4 & 5.85 & 88 \\
\hline $\begin{array}{l}\text { Plantation } \\
\text { Palm }\end{array}$ & $0-30$ & 5.55 & 12.2 & 21 & 1.3 & 4.50 & 1.5 & 1.16 & 0.2 & 0.20 & 0.4 & 0.2 & 3.66 & 83.6 \\
\hline Plantation & $0-30$ & 5.77 & 15.6 & 26.9 & 1.1 & 3.00 & 2.3 & 1.13 & 0.11 & 1.15 & 0.5 & 0.2 & 5.39 & 72.7 \\
\hline Mean & & 5.86 & 14.4 & 24.9 & 1.2 & 4.23 & 2.1 & 1.26 & 0.19 & 0.37 & 0.4 & 0.26 & 4.59 & 82.4 \\
\hline $\operatorname{LSD}(0.05)$ & & 0.32 & 5.41 & 9.37 & 0.50 & NS & NS & NS & NS & 0.37 & 0.13 & 0.08 & NS & NS \\
\hline
\end{tabular}

$\mathrm{TN}=$ Total Nitrogen, OM = Organic matter, NS = not significant at $5 \%$

\section{Variability among Soil Physicochemical Properties in the Study locations}

Results of the relationship among soil physical properties are shown in Table 4. Results showed that there was no variation on sand fraction in the three locations. On silt fraction, no variation existed between cassava cultivated land and palm plantation but variation existed between the two and fallow land. There were variations on the clay fractions in the three locations while no variations existed on soil bulk density, total porosity and moisture content. The parent material dominant in the locations could be responsible for no variations in the sand fraction.

Results of the variation among soil chemical properties are presented in Table 5. Results showed that among the three locations, there were no variations on soil $\mathrm{pH}$ and organic carbon content of the soil while 
Onwudike, Uzoho, Ihem, Ahukaemere, Nkwopara, Irokwe \& Echeanyanwu

Table 4: Variability among Soil Physical Properties

\begin{tabular}{|c|c|c|c|c|c|c|}
\hline & Sand & Silt & Clay & $\mathrm{BD}$ & TP & MC \\
\hline \multicolumn{7}{|c|}{ Fallow Land } \\
\hline$\% \mathrm{CV}$ & 7.6 & 21.2 & 28.6 & 13.7 & 8.8 & 18.7 \\
\hline Ranking & Low & Medium & Medium & Low & Low & Medium \\
\hline \multicolumn{7}{|c|}{ Cassava Farm } \\
\hline$\% \mathrm{CV}$ & 1.8 & 37.3 & 12.2 & 3.8 & 2.8 & 16.3 \\
\hline Ranking & Low & High & Low & Low & Low & Medium \\
\hline \multicolumn{7}{|c|}{ Palm Plantation } \\
\hline$\% \mathrm{CV}$ & 6.2 & 35.2 & 31.9 & 9.5 & 5.6 & 23.6 \\
\hline Ranking & Low & High & Medium & Low & Low & Medium \\
\hline
\end{tabular}

there was variation in the total nitrogen, available phosphorus and exchangeable bases. Variation also occurred in ECEC and exchangeable acidity. These little variations could be due to different management practices existing in these three land use types such as tillage practices that alter the chemical equilibrium of the soil.

Table 5: Variability among Soil Chemical Properties

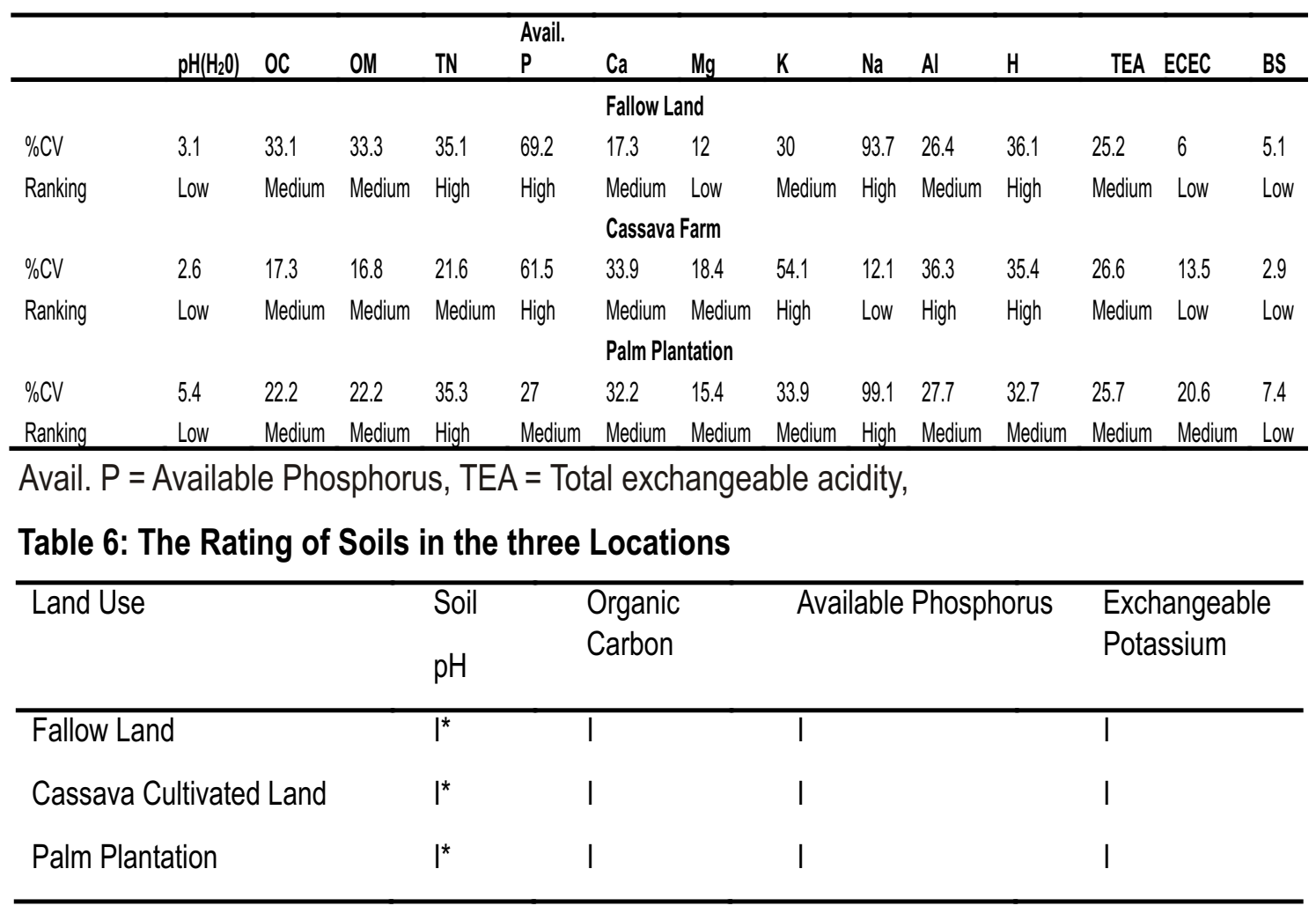




\section{The Fertility Rating and Nutrient Index of Soil in the Study Locations Using Soil pH, Organic Carbon, Available P and Exchangeable K}

Results of the fertility rating of soils in the study locations are presented in Table 6. Results showed that the $\mathrm{pH}$ of soils in the three locations were acidic (below 6.0). Soil organic carbon was low (below $5.0 \mathrm{~g} / \mathrm{kg}$ ), available phosphorus was low (below $22 \mathrm{mg} / \mathrm{kg}$ ) while exchangeable potassium was also low (below $1.23 \mathrm{Cmol} / \mathrm{kg}$ ). This finding showed that the fertility status of soil in these three locations were low and therefore demand appropriate management practices that will boost the fertility status. These findings are in concord with Onweremadu, (2007) and Mbah (2006) that soils in Southeastern Nigeria are low in fertility level. This poor fertility status could be due to high rainfall in the area which increases soil erosion and leaching of plant nutrient elements. Also, the dominant sand fraction of soil due to parent material (coastal plain sand) could contribute to soil acidity and low nutrient elements in the soil. Results of the nutrient index of soils in the study locations as presented in Table 7 showed that the soil organic carbon, available phosphorus and exchangeable potassium had low nutrient index confirming low fertility level of soils in the study locations.

Table 7: Nutrient Index Values of Soils in the Study Locations

\begin{tabular}{llll}
\hline Land Use & Soil Properties & Nutrient Index & Remark \\
\hline Fallow Land & Organic Carbon & 1.00 & Low \\
Cassava Cultivated Land & Available P & 1.00 & Low \\
Palm Plantation & Exchangeable K & 1.00 & Low \\
\hline
\end{tabular}

\section{Conclusion}

This investigation has shown that the fertility status of soils in this part of Imo State, Southeastern Nigeria is poor according to the rating index used in this work. Due to high acidity of soils in the area together with high rainfall that facilitates leaching and runoff of plant nutrients, farmers should adopt organic farming and application of lime. Animal droppings, kitchen wastes and biodegradable materials that will after decomposition add humus to the soil should be applied. Farmers should be discouraged from applying chemical fertilizers that will worsen the situation as this will cause nutrient imbalance, low nutrient availability due to low soil pH and low soil biodiversity. Mulching of soils after tillage in cassava cultivated land and even other crops should be encouraged. This will reduce the impact of raindrops on soil; improve soil condition and growth of soil microbes. Duration of fallow land should be increased in areas where land fragmentation is not a problem. Allowing longer fallow period will increase litter fall and organic matter turnover.This method of soil fertility evaluation should be used to evaluate the fertility status of soils in other agro-ecological zone because the methods are reliable. 


\section{REFERENCES}

Agbede, T.M and Adekiyan, A. O. (2012). "Effect of wood ash, poultry manure and NPK fertilizer on soil and leaf nutrient composition, growth and yield of okra (Abelmoschus esculentus)". Emir. Journal of Food and Agric. 24(4): 314321.

Arunah, U. L and Ibrahim, $\mathrm{H}$ (2004). "Effect of inorganic fertilizer and poultry manure on sorghum yield at Samaru in the Northern Guinea Savanna of Nigeria". Agrosearch Journal , 6(1): 49 - 54.

Brady, N.C. and Weil, R.R. (2002). "The nature and properties of soils", 13th Ed. Prentice- Hall Inc., New Jersey, USA. 960p.

Bremner, J. M and Yeomans, J. C. (1988). "Laboratory Techniques for determination of different forms of nitrogen". In: J, R. Wilson (ed.). Advances in Nitrogen Cycling in Agricultural Ecosystem, pp $339-414$.

Cambardella, C. A, Moorman, T. B, Novak, J. M (1994). "Field-scale variability of soil properties in central lowa soils". Soil Science Society of America Journal, 58; 1501-1511.

Eswaran, H., Lal, R. and. Reich, P. F. (2001). "Land degradation; an overview". In: Bridges, E. M, I. D. Hannam, L. R. Oldeman, F. W.T. Peningde, S.J. Scherr and S. Sompatpanit (Eds.) Response to land degradation. Proceedings of $2^{\text {nd }}$ International Conference of Land Degradation and Desertification, Khonkaen, Thailand, Oxford Press, New Delhi.

Fagbenro, J. A, Oshunsanya, S. O and Onawumi, O.A. (2013). "Effect of saw dust biochar and NPK 15: 15: 15 inorganic fertilizer on moringa oleifera seedlings in an oxisol". Agrosearch 13(1): $57-68$.

Gee, G. W and Or. D. (2002). "Particle size analysis". In: Methods of Soil Analysis. Dan. D. J and Topps G.C (Ed.). Part 4, Physical Methods. Soil Sci. Soc. Of America Book Series. No. 5, ASA and SSSAMadison, WI, PP 225 - 293.

Grossmans, R. B and Reinch, T. G. (2002). "Bulk density and linear extensibility". In: methods of soil analysis. Part 4 Physical Methods. Dane, J.H and G.C Topp (eds.). Soil Science Society of Am. Book Series, No 5ASA and SSAMadison, W. I, pp 201-228.

John, N. M., Uwah, D. F., Iren, O. B. and Akpan, J. F. (2013). "Changes in maize (zea mays L) performance and nutrient content with the application of poultry manure, municipal solid wastes and ash composts". Journal of Agricultural Science. Vol. 5(3): 270-277.

Kayombo, B and Lal, R. (1984). Cited by Lal, R. (1986). "Land clearing and development in the tropics".In: Bulkerma Publications, pp 299-308.

Mbah, C. N. (2006). "Influence of organic wastes on plant growth parameters and nutrient uptake by maize (zea mays L.)". Nigerian Journal of Soil Science. 16:145 150.

Mclean, E. D. (1982). "Soil pH and lime requirements". In: Page A.L. (Ed). Methods of soil analysis part 2. Chemical and microbiological properties (2nd Ed.). Agronomy series No. SSSA. Maidison, Wis. USA., pp: 199-234.

Miller, R.W. and Grardiner, D.T (2001). "Soils in our environment" 9th Ed. Prentice-Hall Inc., Englewood Cliffs, New Jersey. 671p. 
Nelson, D. W. and Sommers, L. E. (1982). "Total organic carbon and matter". In: Methods of soil analysis. Part 2 chemical and microbiological properties (2nd ed.). Agronomy series No.9, ASA, SSA, Maidison, Wis.USA., pp: 570.

Oguike, P. C. and Mbagwu, J. S. C. (2009). "Variations in some physical properties and organic matter content of soils of coastal plain sand under different land use types". World J. Agric. Sci., 5:63-69.

Olabode, O. S. (1997). "Comparison of the physical and chemical properties of soils under natural forest and Gmelina plantation". Agrosearch Journal, Vol 3(1 and 2): 19-30

Oladipo, O. G; Olayinka, A; Aladesanmi, O. T; Sanni, M; Famurewa, A. J. and. Siyanbola, W. O. (2010). "Risk mitigation stratedies and policy implications for carbon dioxide emission in organically amended soils in Nigeria". African Journal of Environmental Sci. and Technology. Vol. 4 (11): 801806.

Olsen, S. R. and Sommers, I. E. (1982). "Soil available phosphorus". In: Methods of Soil Analysis, Part 2. Agron., Mono. ASA and SSSAMadison, USA.

Onweremadu, E. U. (2007). "Lithosequential variability in phosphorus $(P)$ forms in the humid tropics". International Journal of Soil Science, 2(3): 182187.

Onwudike, S.U. (2010). "Effectiveness of Cow Dung and Mineral Fertilizer on Soil Properties, Nutrient Uptake and Yield of Sweet Potato (Ipomoea batatas) in Southeastern Nigeria". Asian Journal of Agricultural Research. 4 (3): 148154.

Onwudike, S. U, Ihem, E. E. Irokwe I. F. and Onwuso, G. (2015). "Variability in the Physico-chemical Properties of Soils of Similar Lithology in Three Land Use Types in Ahiazu Mbaise, Imo State Nigeria". Journal of Agriculture and Crops, Vol. 1(3):38-43.

Ravikumar, P, Somashekar, K.R. (2013). "Evaluation of nutrient index using organic carbon, available $P$ and available $K$ concentrations as a measure of soil fertility in Varahi River basin, India". Proceedings of the International Academy of Ecology and Environmental Sciences, 2013, 3(4): 330-343

Senjobi, B.A (2007). "Comparative assessment of the effects of land use and land types on soil degradation and productivity in Ogun State, Nigeria", Published Ph.D. Thesis submitted to the Dept of Agronomy, University of Ibadan, Ibadan, pg 161.

Tekwa, I. J. and Bethel, M. D. (2008). "Effectiveness of some localized soil and water conservation techniques on sustainable crop production in Mubi, Adamawa state". A Paper Presented at the 32nd National Conference of the Soil Science Society of Nigeria (SSSN). Yola, Nigeria, pp. $138-146$

Thomas, G. W. (1982). "Exchangeable Cations". In: A. L. Page, A. Miller and D.R. Keeney (2nd Ed.). Methods of Soil Analysis. Part 2, ASA and SSSA, Madison, WI, PP 159166.

Wilding, L.P, Bouma, J. and Boss, D. W. (1994). "Impact of spatial variability on interpretative modelling". In: Bryant R. B. and R. W. Arnold. Quantitative Modelling of Soil Forming Process, SSSA Special Publication, No., 39:61 - 75.

Woldeamlak, B and Stroosnijder, L. (2003). "Effects of agro-ecological land use succession on soil properties in the Chemoga watershed, Blue Nile basin". Ethiopia. Geoderma. 111: 8598.properties in the Chemoga watershed, Blue Nile basin". Ethiopia. Geoderma. 111:85-98. 